University of Nebraska - Lincoln

DigitalCommons@University of Nebraska - Lincoln

Faculty Publications from the Harold W. Manter Laboratory of Parasitology

$10-1965$

Studies on the Helminth Fauna of Alaska. XLIII. Strigea macropharynx sp. n., a Trematode Parasite of Falco rusticolus $\mathrm{L}$.

Georges Dubois

Corcelles (Neuchâtel)

Robert L. Rausch

University of Washington, rausch@uw.edu

Follow this and additional works at: https://digitalcommons.unl.edu/parasitologyfacpubs

Part of the Parasitology Commons

Dubois, Georges and Rausch, Robert L., "Studies on the Helminth Fauna of Alaska. XLIII. Strigea macropharynx sp. n., a Trematode Parasite of Falco rusticolus L." (1965). Faculty Publications from the Harold W. Manter Laboratory of Parasitology. 367.

https://digitalcommons.unl.edu/parasitologyfacpubs/367

This Article is brought to you for free and open access by the Parasitology, Harold W. Manter Laboratory of at DigitalCommons@University of Nebraska - Lincoln. It has been accepted for inclusion in Faculty Publications from the Harold W. Manter Laboratory of Parasitology by an authorized administrator of DigitalCommons@University of Nebraska - Lincoln. 


\title{
STUDIES ON THE HELMINTH FAUNA OF ALASKA. XLIII. STRIGEA MACROPHARYNX SP. N., A TREMATODE PARASITE OF FALCO RUSTICOLUS L.
}

\author{
Georges Dubois and Robert L. Rausch \\ Corcelles (Neuchâtel), Switzerland, and Arctic Health Research Center, Public Health Service, \\ U. S. Department of Health, Education, and Welfare, Anchorage, Alaska
}

ABSTRACT: Strigea macropharynx sp. n. (Trematoda : Strigeata, Strigeidae), an intestinal parasite of Falco rusticolus L., is described. Falconiformes harbor two species of Strigea (S. falconis Szidat, 1928, and S. macroconophora Dubois and Rausch, 1950) with vitellaria terminating near the copulatory bursa. Both differ from the new species in having a pharynx that is smaller than or subequal to the buccal sucker, as well as in other details. In S. elegans Chandler and Rausch, 1947, a parasite of Strigiformes, the eggs are larger, the testes of different form, and the vitellaria extend significantly farther into the region of the copulatory bursa. The very intimate contact existing between the tribocytic organ of $S$. macropharynx and the intestinal mucosa of the host suggests that extracorporeal digestion of host tissue takes place.

Twenty-six specimens of the trematode described herein were found among numerous neodiplostomes, Neodiplostomum (Conodiplostomum) spathula banghami Penrod, 1947, in the small intestine of a gyrfalcon, Falco rusticolus L. This bird (No. 31001), an adult female, was collected on 19 April 1964, at its nest in upper Keruktagiak Creek, about 18 miles northwest of Chandler Lake, central Brooks Range, Alaska. The intestine was immediately removed and opened in order to prevent degenerative changes in the helminths. Because of severe cold, the material could not be fixed until some hours later, at which time some of the trematodes nevertheless could be preserved in situ.

\section{Strigea macropharynx sp. $n$.}

(Figs. 1 and 2)

(All measurements in microns unless otherwise indicated; averages in parentheses)

\section{Diagnosis}

Length of body 0.79 to $2.11 \mathrm{~mm}$ (avg 1.98). Anterior segment utricular to pyriform, more or less arched (curved) and convex dorsally, longer than wide, and narrower than posterior segment, 0.45 to $0.70 \mathrm{~mm}$ (avg 0.59) in length and 0.32 to $0.48 \mathrm{~mm}$ (avg 0.40 ) in width. Posterior segment cylindrical, with maximum width at level of testes, 1.27 to $1.54 \mathrm{~mm} \mathrm{(avg} \mathrm{1.39)} \mathrm{in} \mathrm{length} \mathrm{and}$ 0.38 to $0.60 \mathrm{~mm}$ (avg 0.45 ) in width; copulatory bursa, delimited by constriction or diminution in diameter of body, provided with moderately developed muscular ring ("Ringnapf"). Dimensions of terminal buccal sucker 100 to 140 by 105 to 140. Pharynx ovoid, 135 to 165 by 110 to 145 ,

Received for publication 19 March 1965. much larger and more muscular than latter. Ventral sucker 195 to 245 by 150 to 220 . Cucumiform proteolytic gland, 150 to 210 by 70 to 105 , situated at base of anterior segment, oriented dorsoventrally or obliquely in direction of ventral sucker, sometimes tangent to latter. Ovary reniform, at dorsal hilum, 125 to 180 by 100 to 135 , situated between $34 / 100$ and 45/100 (avg 41/100) of posterior segment. Laurer's canal present. Testes coarsely lobed, anterior testis 200 to 250 by 250 to 380 ; posterior, 200 to 310 by 270 to 390 . Seminal vesicle posttesticular and dorsal. Vitellaria of anterior segment concentrated in lobes of tribocytic organ, extending in latter to middle or to anterior margin of ventral sucker, and diffusing beyond into dorsal, preacetabular mass; follicles much more abundant in posterior segment, chiefly ventral and extending to level of anteroventral margin of copulatory bursa. Vitelline reservoir and Mehlis' gland intertesticular. Hermaphroditic canal cylindrical, muscular, from 210 to 260 in length, with walls 10 to 18 thick; opening subterminal, slightly dorsal, near summit of genital cone, latter 85 to 120 in diameter when exserted. Genital atrium 135 to 170 in depth. From 16 to 50 eggs present, with average dimensions of 105 by 60 .

Host: Falco rusticolus L.

Habitat: Small intestine.

Type locality: Head of Keruktag̊iak Creek (lat $68^{\circ} 22^{\prime} \mathrm{N}$, long $150^{\circ} 59^{\prime} \mathrm{W}$ ), central Brooks Range, Alaska.

Type: In the collection of the senior author, Zoological Institute, University of Neuchâtel.

Paratypes: USNM Helm. Coll. No. 60891.

\section{DISCUSSION}

Strigea macropharynx sp. $\mathrm{n}$. is characterized by the large size of its very muscular pharynx [ratio of lengths of pharynx/anterior segment $=0.20$ to $0.30(\operatorname{avg} 0.26)]$, and by the presence of a long, cylindrical hermaphroditic 


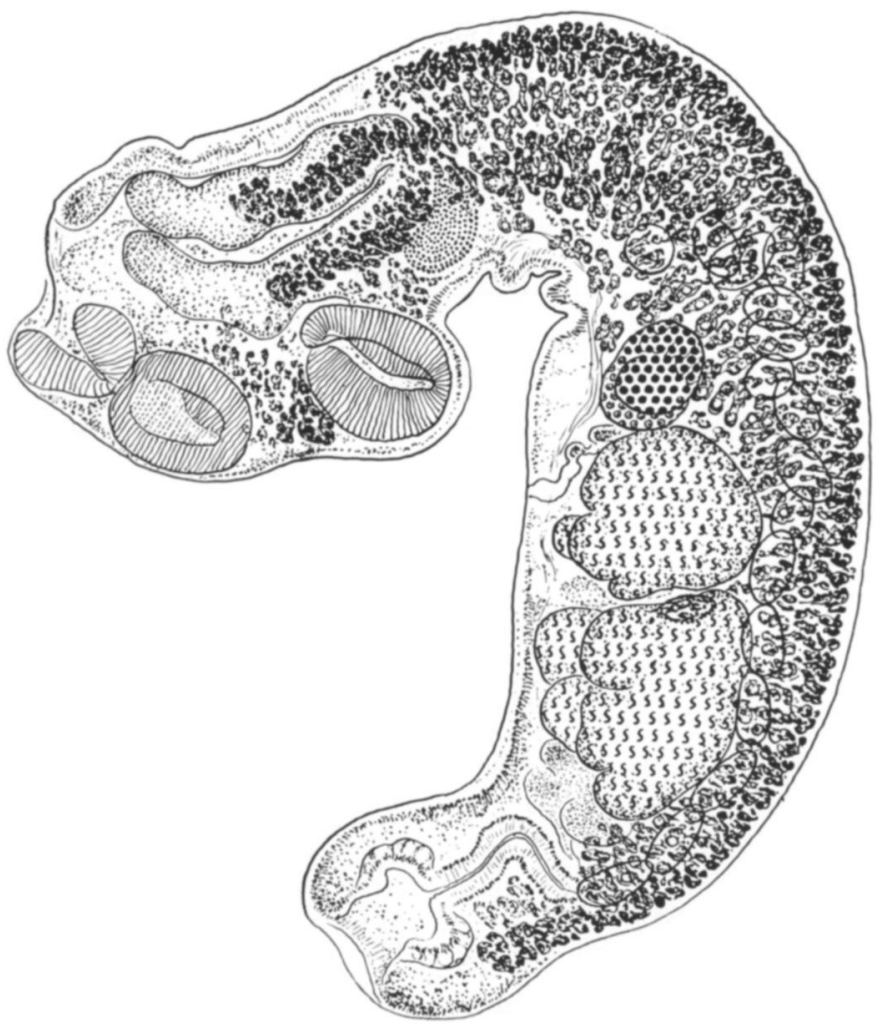

Figure 1. Strigea macropharynx sp. n., from Falco rusticolus L. Type specimen, length $2.11 \mathrm{~mm}$.

canal with muscular walls bordered externally by small, probably prostatic, cells. This canal does not emerge at the summit of the genital cone, but nearby on the dorsal surface; its opening is therefore subterminal.

Strigea macropharynx may be compared with S. falconis Szidat, 1928 (a cosmopolitan species) and S. macroconophora Dubois and

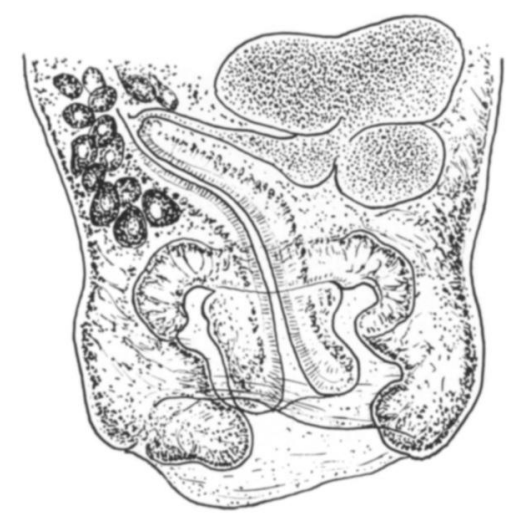

Rausch, 1950 (North America), both occurring in Falconiformes, and both with vitellaria terminating near the copulatory bursa, and with S. elegans Chandler and Rausch, 1947, a parasite of Strigiformes (North America). In these three species, the pharynx is smaller than the buccal sucker or subequal to it.

S. falconis is of larger size (up to $5.25 \mathrm{~mm}$

Figure 2. S. macropharynx. Details of posterior end of two specimens. 
long) and has a distinctly delimited copulatory bursa of different structure (Szidat, 1929; Dubois, 1938).

S. macroconophora is well characterized by the size of the genital cone ( 0.34 to 0.66 by 0.40 to $0.51 \mathrm{~mm}$ ) (Dubois and Rausch, 1950a).

$\mathrm{S}$. elegans is distinguished by the large dimensions of the eggs ( 115 to 125 by 65 to $75 \mu$ ) and by the form of the testes (see Chandler and Rausch, 1947, fig. 2; Dubois and Rausch, 1950b, fig. 9; Pearson, 1959, fig. $1)$; the vitellaria penetrate ventrally into the wall of the copulatory bursa to the level of the excretory pore, or reach nearly the end of the body.

At the time of fixation, some individuals of S. macropharynx were still attached to the intestinal mucosa of the host. The removal of such specimens left relatively deep crater-like cavities, as a result of tearing away the mucosal tissue enveloped by the tribocytic organ. In serial sections of trematodes fixed in situ a particularly intimate contact was noted between the tribocytic organ and the intestinal mucosa (Fig. 3). This finding supports the hypothesis that extracorporeal digestion of mucosal cells takes place, as observed by Lee (1962) for Diplostomum phoxini (Faust, 1918), in the intestine of ducklings, and by Erasmus and Öhman (1963) in the case of Cyathocotyle bushiensis Khan, 1962, in the intestine of ducks. Although the material from the gyrfalcon was not fixed promptly enough to prevent some degeneration of the mucosa, it could be determined from sections stained in hematoxylin-eosin that the trematodes evoked no local tissue reaction.

\section{LITERATURE CITED}

Chandler, A. C., and R. L. Rausch. 1947. A study of strigeids from owls in north central United States. Tr. Am. Micr. Soc. 66: 283292.

DuboIs, G. 1938. Monographie des Strigeida (Trematoda). Mém. Soc. Neuchâtel. Sci. Nat. 6: $1-535$.

, AND R. L. Rausch. 1950a. A contribution to the study of North American strigeids (Trematoda). Am. Midl. Nat. 43: 1-31.

- AND $1950 \mathrm{~b}$. Troisième contri-

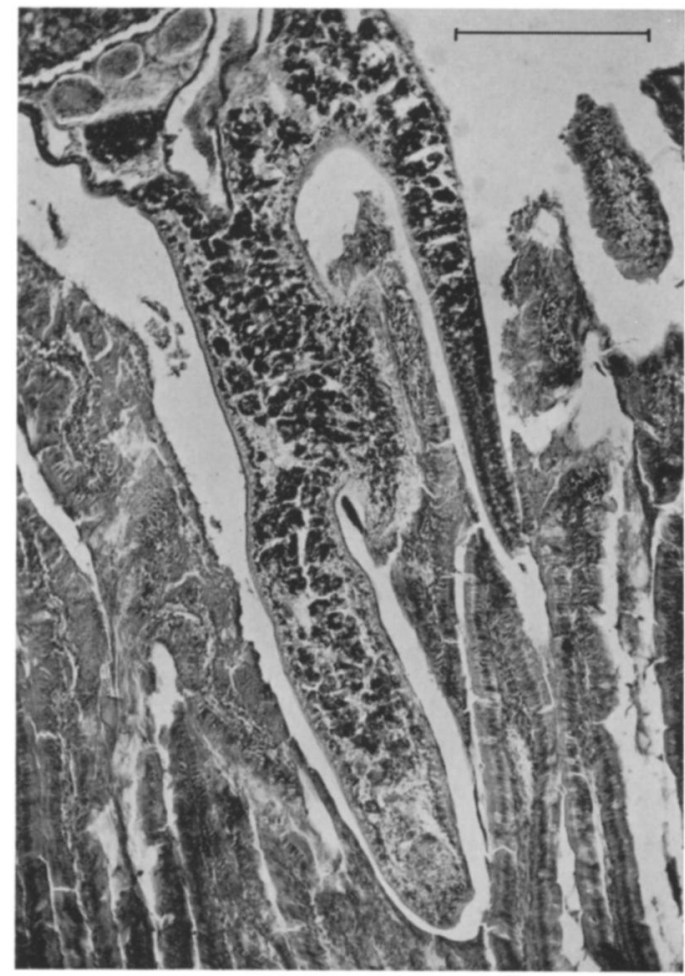

Figure 3. Anterior end of S. macropharynx, in situ, showing intimate connection between tribocytic organ and host tissue. Tissue section stained with Alcian blue-PAS. Scale has value of $250 \mu$.

bution à l'étude des strigeides (Trematoda) nord-américains. Bull. Soc. Neuchâtel. Sci Nat. 73: 19-50.

Erasmus, D. A., and C. Öhman. 1963. The structure and function of the adhesive organ in strigeid trematodes. Ann. N. Y. Acad. Sci. 113: $7-35$

LEE, D. L. 1962. Studies on the function of the pseudosuckers and holdfast organ of Diplostomum phoxini Faust (Strigeida, Trematoda). Parasitology 52: 103-112.

Pearson, J. C. 1959. Observations on the morphology and life cycle of Strigea elegans Chandler \& Rausch, 1947 (Trematoda: Strigeidae). J. Parasit. 45: 155-174.

Szidat, L. 1929. Beiträge zur Kenntnis der Gattung Strigea (Abildg.). II. Spezieller Teil: Revision der Gattung Strigea nebst Beschreibung einer Anzahl neuer Gattungen und Arten. Ztschr. Parasitenk., Berl. 1 : 688764. 